\title{
MICROBIAL EXAMINATION OF MOULD AND YEAST IN FRUIT JUICES
}

\author{
Ayesha Alam ${ }^{1}$, Shabnum Shaheen ${ }^{1}$, Muhammad Ashfaq,", Muhammad Ali², Javed Iqbal Watto ${ }^{2}$, \\ Mubarak Ali Anjum ${ }^{1}$, Farah Khan ${ }^{1}$, Sumaira Maqsood ${ }^{1}$ and Muhammad Sajjad ${ }^{4}$
}

\author{
${ }^{1}$ Department of Botany, Lahore College for Women University, Pakistan; ${ }^{2}$ Institute of Agricultural Sciences, \\ University of the Punjab, Lahore, Pakistan; ${ }^{3}$ Department of Biotechnology, Faculty of Life Sciences, University of \\ Central Punjab, Lahore, Pakistan; ${ }^{4}$ Department of Environmental Sciences, COMSATS University Islamabad, \\ Vehari campus 61100, Pakistan. \\ *Corresponding author's email: ashfaq.iags@pu.edu.pk
}

Fruit juices consists of water, carbohydrates, protein, lipids, acids, phenolics, dietary fibre and pigments that play a vivacious part in human nutrition, as they supply vitamins and essential minerals which are necessary growth factors in human diet and that can assist in maintenance of a good and healthy life. However due to their short shelf life these juices either glass bottles, plastic bottles, paper cups and plastic cups or unpacked can be contaminated by micro flora (especially mould and yeast) and can become a source of health hazard. Hence current study was focused to examine the diversity of mould and yeast contaminants in different types of packed and unpacked fruit juices (pH ranges from 3.35 to 4 ) of six different localities of Lahore such as Chouburji, Govt College of Science, Mozang, Muslim Town, Shadman and Iqbal town. The fungal contaminants (mould and yeast) isolated from their respective juices were cultured on malt extract agar as well as on potato dextrose agar under sterilized conditions. Serial dilution technique was used to compose the replicates in order to get viable count of micro flora in juices samples. Results indicated that in case of packed juices, the maximum fungal viable count was found in samples of Shadman $\left(10 \times 10^{-4}\right.$ to $\left.14 \times 10^{-5} \mathrm{cfu} / \mathrm{ml}\right)$ while minimum was found in Chouburji samples $\left(2 \times 10^{-4}\right.$ to $5 \times 10^{-3}$ $\mathrm{cfu} / \mathrm{ml})$. The highest mould $(803000 \mathrm{cfu} / \mathrm{ml})$ in packed juices was found in locality of Mozang, but lowest value was observed in samples obtained from Muslim town i.e., $16000 \mathrm{cfu} / \mathrm{ml}$. However, yeast contaminants were found in great concentrations in Shadman samples $(71000 \mathrm{cfu} / \mathrm{ml})$ and least count was found in locality of Iqbal town i.e., $200000 \mathrm{cfu} / \mathrm{ml}$. For unpacked (fresh) juices the peak value of fungal viable count was observed in Shadman $\left(8 \times 10^{-5}\right.$ to $14 \times 10^{-5}$ and $\left.18 \times 10^{-5}\right)$ while minimum was found in GCS $\left(4 \times 10^{-4}\right.$ to $\left.7 \times 10^{-3}\right)$. The uppermost value of mould count $(1800000 \mathrm{cfu} / \mathrm{ml}$ was also observed in locality of Shadman and least mould $(25000 \mathrm{cfu} / \mathrm{ml})$ in unpacked juices was found in locality of GCS. Whereas maximum yeast i.e., $400000 \mathrm{cfu} / \mathrm{ml}$ was detected in locality of Shadman and least one $11000 \mathrm{cfu} / \mathrm{ml}$ was reported in Chouburji. Reported fungal species were Aspergillus niger, Aspergillus terreus, Penicilium digitatum, Curvularia americanna, Fusarium moniliforme, Alterneria alternate and Saccharomyces cerevisae. Results indicated that mould and yeast (fungal) count is much more standard tolerable range $\left(10^{2}\right.$ to $\left.10^{3} \mathrm{cfu} / \mathrm{ml}\right)$ hence this negligence and unawareness can lead to serious health damage of consumers.

Keywords: Microorganisms, microbial contaminants, spoilage yeasts, public health, fruit quality, consumer safety.

\section{INTRODUCTION}

Fruit juices are well recognized for their nutritive value, mineral and vitamin content (Sharma et al., 2013). Consumption of fruit and vegetable products has increased by more than 30\% during the past few decades (Barth et al., 2009). They are very nutritive, invigorating and non-alcoholic beverages, which are liked throughout the world. In recent years these juices have been included significantly in diet of every person irrespective of age (Basar and Rahman, 2007). They are very scrumptious and palatable and they have most of the minerals like calcium, magnesium, phosphorus, and sodium as well as vitamins specially vitamin C (FDA, 1999). Processed juices contain mainly water, sugar, preservatives, color, fruit pulps and other additives as ingredients and must maintain sanitary standard (Levine, 1961).

The consumption of fruit juices could have both positive and negative effect on the consumers (Sharma et al., 2013). Freshly extracted fruit juices, have always considered as healthful drink, and may not always be safe owing to the heavy load of microbes (Kumari, 1995). Most fruit juices contain sufficient nutrients that could support microbial growth (Basar and Rahman, 2007). The major ingredients of the juice such as water, sugar, natural fruit pulp etc. may also carry some microbial contaminants (Rahman et al., 2010). Fruit juices contain various concentration of sucrose that constitutes a very important component of the medium for the growth of fungi (Palou et al., 1998). Microbial spoilage is a serious problem for the food industry as microbe can be any 
contamination can occur during processing as well as handling of the end products (Koc et al., 2007).

Mould and yeast are sub classes of fungus and they are most notorious contaminants of fruit juices. Especially yeast spoilage has increased in recent years as a result of lower doses of preservatives and milder preservation processes, required for higher standards of food quality (Beuchat and Golden, 1989). Spoilage yeasts, such as Saccharomyces cerevisiae, Candida lipolytica and Zygosaccharomyces spp. can tolerate acidic environments (ICMSF, 1980). Moulds are generally considered to be the least important group of microorganisms causing spoilage in fruit juice because of their limitation, inability to grow in the absence of air, with the exception of some moulds such as Penicillium and Aspergillus (Parish, 1991; Parish and Higgin, 1989). Aspergillus niger and A. flavus are the common allergens and may cause opportunistic invasive infections (Dehoog et al., 2000; Denning, 1998; Mau et al., 2002).

Juices squeezed from fresh fruits and vegetables are good for health but they may contain microorganisms which are potentially hazardous to public health. Maintaining the quality of processed fruit juices is important issue now because contaminated juices can transmit disease to people. Mainly moulds and yeasts are involved in juice spoilage. Hence there is need to explore which mold and yeast species are involved in juice quality deterioration so that specific sterilization procedure is followed to ensure juice quality. The specific aims and objectives of current study were to grow mould and yeast culture in different packed and unpacked juices, examine diversity of mould and yeast in studied juice samples, and highlight the conditions which enhance the mould and yeast proliferation in juices.

\section{MATERIALS AND METHODS}

Sample collection: Various samples of packed and unpacked fruit juices were collected from different localities of the Lahore city (Chouburji, Govt College of Science, Mozang, Muslim Town, Shadman and Iqbal town) in months of February to May 2015.

Packaging of packed juices: Selected samples were packed in tetra packages, Glass bottles and canned juices.

$\boldsymbol{p H}$ : $\mathrm{pH}$ of all collected samples was measured using $\mathrm{pH}$ meter and litmus paper. Almost all samples were alkaline in nature (Wang et al., 1992).

Sterilization: Sterilizer (Memmert oven) was pre heated at $180^{\circ} \mathrm{C}$ for 20 minutes. Petri plates and pipette were put in the sterilizer for 2 hours.

Media preparation: The preparation of different ratio of malt extract and potato dextrose media was shown in Table 1 and Table 2.
Table 1. Malt extract agar.

\begin{tabular}{clc}
\hline Sr.\# & Chemicals & Weight \\
\hline 1. & Malt extract & 2 grams \\
2. & Agar & 2 grams \\
3. & Water & $100 \mathrm{ml}$ \\
\hline
\end{tabular}

Table 2. Potato dextrose agar.

\begin{tabular}{clc}
\hline Sr.\# & Chemicals & Weight \\
\hline 1. & Potato dextrose agar & 4 grams \\
2. & Water & $100 \mathrm{ml}$ \\
\hline
\end{tabular}

Four gram of potato dextrose agar was weighed and poured in to a beaker. $100 \mathrm{ml}$ of water was added to potato dextrose agar and the solution was heated for 2-3 minutes. Continuous stirring was provided to the solution during heating to make homogenous mixture. After preparation of potato dextrose agar saturated solution of $10 \mathrm{ml}$ was poured in a three test tubes. The test tubes were then covered tightly with cotton plugs. Liquid form media was autoclaved at about $15 \mathrm{lbs}$ and $121^{\circ} \mathrm{C}$.

Serial dilution: For the observation of colony forming unit of fungal flora, $1 \mathrm{ml}$ of juice sample was suspended in sterilized test tube containing $9 \mathrm{ml}$ of sterilized distilled water. This test tube was well shaken which gave dilution of 1:10. Afterwards $1 \mathrm{ml}$ of suspension from 1: 10 was transferred to second test tube which gave 1:100 dilutions. Similarly 1:1000, 1:10000 and 1:100000 dilutions were made.

Inoculation: $1 \mathrm{ml}$ aliquot from 1:1000, 1:10000 and 1:100000 dilutions were transferred to the sterilized petri plates and 10$15 \mathrm{ml}$ of molten cooled agar poured containing 20,000 unit/liter penicillin and $200 \mathrm{mg} / \mathrm{liter}$ streptomycin. Petri dishes were incubated at $30 \pm 2^{\circ} \mathrm{C}$ for 5-7 days.

Identification: The methods adopted for identification of fungi include morphological characteristics and methods described in "Fungi and Food Spoilage" (Pitt and Hocking, 2009).

Quantification: Mould and Yeast colonies were analyzed quantitatively using methodology of (Webster and Weber, 2007) with slight modifications.

Percentage contribution of each species: To find out percentage contribution following formula was used:

$\%$ contribution $=\frac{\text { Total No of } \mathrm{cfu} / \mathrm{ml} \text { of an individual specie }}{\text { Total no. of } \mathrm{cfu} / \mathrm{ml} \text { of all species }} \times 100$

\section{RESULTS AND DISCUSSION}

Inoculated petri plates with fungal colonies can be seen in Figure 1. LM and SEM images of fungi can be seen clearly in Figure 2 and 3. 


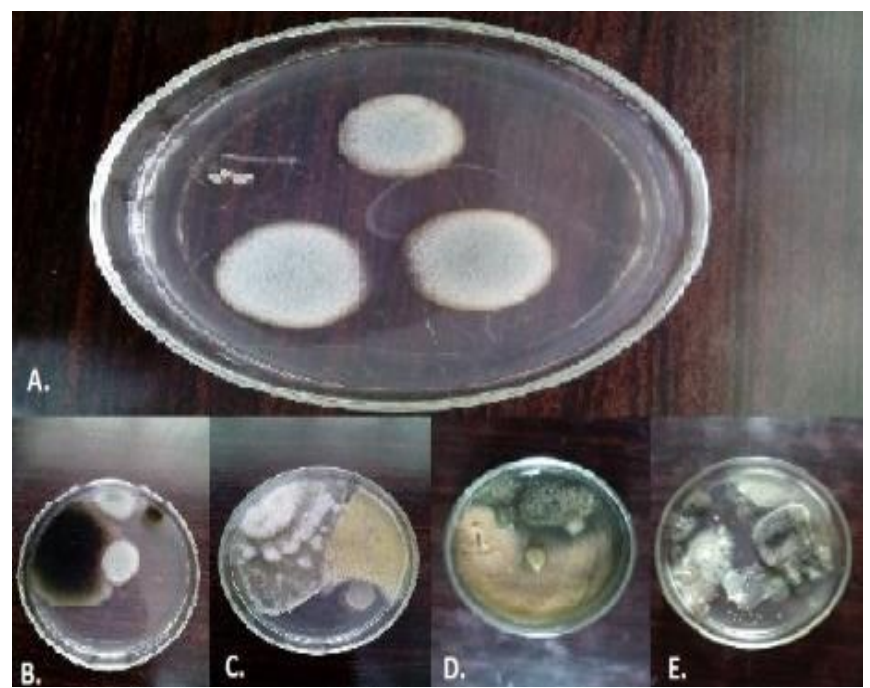

Figure 1. Media showing fungal colonies.

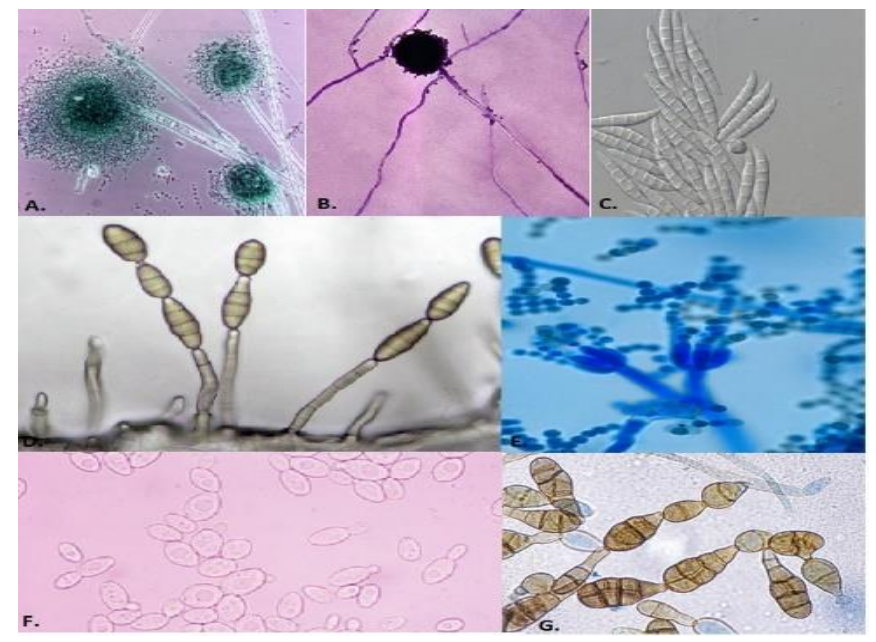

Figure 2. LM examination of mould and yeast.

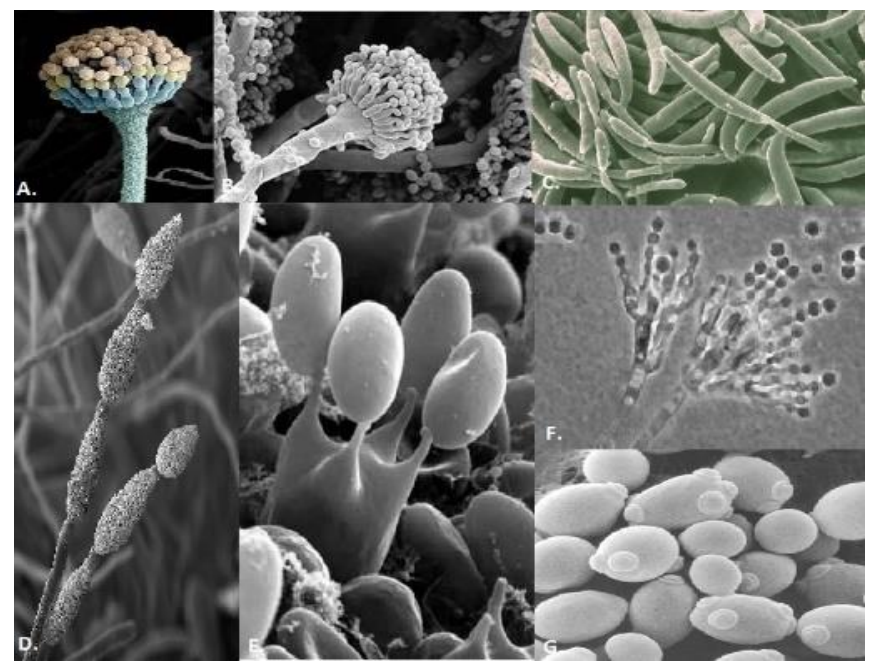

Figure 3. SEM Examination of mould and Yeast.
Packed and unpacked juice samples of Chouburji: Total tested 4 packed and unpacked samples showed total viable count of $2 \times 10^{-4}$ to $5 \times 10^{-3}$ in packed juices whereas, $16 \times 10^{-3}$ to $27 \times 10^{-4}$ in unpacked juices. The highest fungal count was shown by unpacked juices. Results indicated maximum mould count was 260000cfu / ml and least mould count was $15000 \mathrm{cfu} / \mathrm{ml}$, whereas uppermost and lower most yeast count was $10000 \mathrm{cfu} / \mathrm{ml}$ and $1000 \mathrm{cfu} / \mathrm{ml}$ respectively. However, the results of packed juices demonstrated the mould contamination only. The peak mould count was observed as $2,0000 \mathrm{cfu} / \mathrm{ml}$ and least value was calculated as $5000 \mathrm{cfu} / \mathrm{ml}$. There was no yeast count found in packed juice samples. The identified fungi were Aspergillus niger, Alterneria alternate, Fusarium moniliforme, Pennicillim digitatum, Curvularia americana and Saccharomyces cerevisiae.

Packed and unpacked juice samples of Govt. College of Science: Total tested 4 packed and unpacked samples showed total viable count of $4 \times 10^{-4}$ to $9 \times 10^{-5}$ in packed juices whereas, $4 \times 10^{-4}$ to $7 \times 10^{-3}$ in unpacked juices. The highest fungal count was shown by packed juices. Results indicated maximum mould count was $600000 \mathrm{cfu} / \mathrm{ml}$ and least mould count was $40000 \mathrm{cfu} / \mathrm{ml}$ whereas yeast count was only 300000cfu / ml. The results of unpacked juices demonstrated the contamination as well. The peak mould count was observed as $20000 \mathrm{cfu} / \mathrm{ml}$ and least value was calculated as 5000cfu / $\mathrm{ml}$ and reported peak yeast count was 20000cfu / $\mathrm{ml}$ and least one was 2000cfu / ml. The identified fungi were Aspergillus niger, Aspergillua terreus, Alterneria alternate, Fusarium moniliforme, Pennicillim digitatum, Curvularia americana and Saccharomyces cerevisiae Denning, 1998.

Packed and unpacked juice samples of Mozang: Total tested 4 packed and unpacked samples showed total viable count of $10 \times 10^{-5}$ to $4 \times 10^{-3}$ in packed juices whereas, $64 \times 10^{-3}$ to $3 \times 10^{-5}$ in unpacked juices. The highest fungal count was shown by unpacked juices. Results indicated maximum mould count was $100000 \mathrm{cfu} / \mathrm{ml}$ and least mould count was $16000 \mathrm{cfu} / \mathrm{ml}$ whereas uppermost and lower most yeast count was $200000 \mathrm{cfu} / \mathrm{ml}$ and $48000 \mathrm{cfu} / \mathrm{ml}$ respectively. The results of packed juices demonstrated the contamination of mould and yeast. The peak mould count was observed as $800000 \mathrm{cfu} / \mathrm{ml}$ and least value was calculated as $3000 \mathrm{cfu} / \mathrm{ml}$. The peak yeast count was observed as $200000 \mathrm{cfu} / \mathrm{ml}$ and least value was calculated as $1000 \mathrm{cfu} / \mathrm{ml}$. The identified fungi were Aspergillus niger, Penicillium digitatum and Saccharomyces cerevisiae Nazim et al., 2008.

Packed and Unpacked juice samples of Muslim Town: Total tested 4 packed and unpacked samples showed total viable count of $1 \times 10^{-4}$ to $6 \times 10^{-3}$ in packed juices whereas, $11 \times 10^{-4}$ to $5 \times 10^{-5}$ in unpacked juices. The highest fungal count was shown by unpacked juices. Results indicated maximum mould count was $400000 \mathrm{cfu} / \mathrm{ml}$ and least mould count was $10000 \mathrm{cfu} / \mathrm{ml}$ whereas maximum yeast count was $100000 \mathrm{cfu} / \mathrm{ml}$ and minimum yeast count was $10000 \mathrm{cfu} / \mathrm{ml}$ respectively. However the results of packed juices 
Table 3. Qualitative and quantitative characters of fungal species (Mould).

\begin{tabular}{|c|c|c|c|c|c|c|c|}
\hline Sr. & Fungal species & $\begin{array}{l}\text { Shape and } \\
\text { color of } \\
\text { colony }\end{array}$ & $\begin{array}{l}\text { Length and width } \\
\text { of sporangia }\end{array}$ & $\begin{array}{l}\text { Diameter } \\
\text { of spore }\end{array}$ & Conidia & hyphae & $\begin{array}{l}\text { Length and width of } \\
\text { sporangiophore }\end{array}$ \\
\hline 1. & Aspergillus niger & Black & $182.2 \& 253.0 \mu \mathrm{m}$ & $15.8 \mu \mathrm{m}$ & Basipetal & Septate & $187.8 \& 25 \mu \mathrm{m}$ \\
\hline 2. & Alterneria alternata & Black & $151.7 \& 39.5 \mu \mathrm{m}$ & $10.2 \mu \mathrm{m}$ & Beak like & Septate & $144.5 \& 12.5 \mu \mathrm{m}$ \\
\hline 3. & Penicillium digitatum & Green & $51.3 \& 12.5 \mu \mathrm{m}$ & $7.9 \mu \mathrm{m}$ & Basipetal & Aerial hyphae & $122.6 \& 10 \mu \mathrm{m}$ \\
\hline 4. & Curvularia americana & Black to green & $81.9 \& 21.2 \mu \mathrm{m}$ & $16.8 \mu \mathrm{m}$ & Dark and basal & Septate & $198.6 \& 14 \mu \mathrm{m}$ \\
\hline 5. & Fusarium moniliforme & Wooly white & $55.5 \& 43.0 \mu \mathrm{m}$ & $16.5 \mu \mathrm{m}$ & Small & Philades & $387.5 \& 17 \mu \mathrm{m}$ \\
\hline 6. & A. terreus & Brown & $63.9 \& 80.5 \mu \mathrm{m}$ & $10 \mu \mathrm{m}$ & Unicellular & Septate & $222.6 \& 10.6 \mu \mathrm{m}$ \\
\hline
\end{tabular}

demonstrated the contamination as well. The peak mould count was observed as 10000cfu / $\mathrm{ml}$ and least value was calculated as $6000 \mathrm{cfu} / \mathrm{ml}$. There was no reported yeast in packed juice samples. The identified fungi were Aspergillus niger, Aspergillus terreus, Penicillium digitatum, Curvularia americana and Saccharomyces cerevisiae Olorunjuwan et al., 2013.

Packed and Unpacked juice samples of Shadman: Total tested 4 packed and unpacked samples showed total viable count of $10 \times 10^{-4}$ to $14 \times 10^{-5}$ in packed juices whereas, $8 \times 10^{-5}$ to $14 \times 10^{-5}$ in unpacked juices. The highest fungal count was shown by packed juices. Results indicated maximum mould count was $700000 \mathrm{cfu} / \mathrm{ml}$ and least mould count was $90000 \mathrm{cfu} / \mathrm{ml}$ whereas peak yeast count was 700000cfu / ml and least yeast count was 10000cfu / ml respectively. However the results of unpacked juices demonstrated the contamination as well. The peak mould count was observed as $1100000 \mathrm{cfu} / \mathrm{ml}$ and least value was calculated as $700000 \mathrm{cfu} / \mathrm{ml}$ and reported peak yeast count was $300000 \mathrm{cfu}$ / $\mathrm{ml}$ and least one was $100000 \mathrm{cfu} / \mathrm{ml}$. The identified fungi were Aspergillus terreus, Fusarium moniliforme, Pennicillim digitatum, Curvularia americana and Saccharomyces cerevisiae.

Packed and unpacked juice samples of Iqbal Town: Total tested 4 packed and unpacked samples showed total viable count of $1 \times 10^{-5}$ to $5 \times 10^{-5}$ in packed juices whereas, $18 \times 10^{-5}$ to $2 \times 10^{-3}$ in unpacked juices. The highest fungal count was shown by unpacked juices. Results indicated maximum mould count was $800000 \mathrm{cfu} / \mathrm{ml}$ and least mould count was $200000 \mathrm{cfu} / \mathrm{ml}$ whereas yeast count was only $100000 \mathrm{cfu} / \mathrm{ml}$. The results of packed juices demonstrated the contamination as well. The peak mould count was observed as 400000cfu / $\mathrm{ml}$ only and reported peak yeast count was 100000cfu / ml only. The identified fungi were Aspergillus niger, A. terreus, Fusarium moniliforme, and Saccharomyces cerevisiae (Oranusi et al., 2012).

Table 4. Qualitative and quantitative characters of fungal specie (Yeast).

\begin{tabular}{llll}
\hline Sr. & Fungal specie & $\begin{array}{l}\text { Color of } \\
\text { colony }\end{array}$ & $\begin{array}{l}\text { Length and width } \\
\text { of bud }\end{array}$ \\
\hline 1 & $\begin{array}{l}\text { Saccharomyces } \\
\text { cerevisiae }\end{array}$ & Creamy white & $32.5 \& 16.8 \mathrm{um}$ \\
\hline
\end{tabular}

The qualitative and quantitative characters of mould and yeast fungal species were shown in Table 3 and Table 4.

Project scenario: Fruit juice consists of $100 \%$ pure juices and generally has no added ingredients (USDA, 2004). Fruits play a vital role in human nutrition by supplying the necessary growth factors such as vitamins and essential minerals in human daily diet and that can help to keep a good and normal health. Fruits are widely present in nature. One of the limiting factors that influence their economic value is the relatively short shelf-life period caused by pathogens (Al-Hindi et al., 2011). Pathogenic organisms can enter fruits and vegetables through damaged surfaces, such as punctures, wounds, cuts and splits that occur during growing or harvesting (Durgesh et al., 2008). Contamination from raw materials and equipment's, additional processing conditions, improper handling, prevalence of unhygienic conditions contribute substantially to the entry of bacterial pathogens in juices prepared from these fruits or vegetables (Victorian Government Department of Human Services 2005; Oliveira et al., 2006; Nicolas et al., 2007; Durgesh et al., 2008).

Total viable count in packed juices: The present study illustrated the presence of seven different fungal isolates in different localities of Lahore such as Chouburji, GCS, Mozang, Muslim Town, Shadman and Iqbal town. The total viable count in packed juices was found as $2 \times 10^{-4}$ to $5 \times 10^{-3}$, $4 \times 10^{-4}$ to $9 \times 10^{-5}, 10 \times 10^{-5}$ to $4 \times 10^{-3}, 1 \times 10^{-4}$ to $6 \times 10^{-3}, 10 \times 10^{-4}$ to $14 \times 10^{-5}$ and $1 \times 10^{-5}$ to $5 \times 10^{-5} \mathrm{cfu} / \mathrm{ml}$ in Chouburji, GCS, Mozang, Muslim Town, Shadman and Iqbal town respectively. The maximum fungal viable count was found in Shadman $\left(10 \times 10^{-4}\right.$ to $\left.14 \times 10^{-5} \mathrm{cfu} / \mathrm{ml}\right)$ while minimum was found in Chouburji $\left(2 \times 10^{-4}\right.$ to $\left.5 \times 10^{-3} \mathrm{cfu} / \mathrm{ml}\right)$. Among total viable count mould and yeast count was determined, and it varied from locality to locality. The total mould count in packed juices was reported as 25000, 640000, 803000, 16000, 790000, and 400000 in as Chouburji, GCS, Mozang, Muslim Town, Shadman and Iqbal Town respectively. The highest mould (803000 cfu / ml) in packed juices was found in Mozang, however lowest value of mould (16000 cfu / ml) in packed juices was found in Muslim town. Yeast content also contaminated the samples of different localities and in the study maximum yeast $(200000 \mathrm{cfu} / \mathrm{ml}$ ) in packed juices was found in Shadman and least count was found in Iqbal town i.e., $71000 \mathrm{cfu} / \mathrm{ml}$ (Figure 4 and 6). 


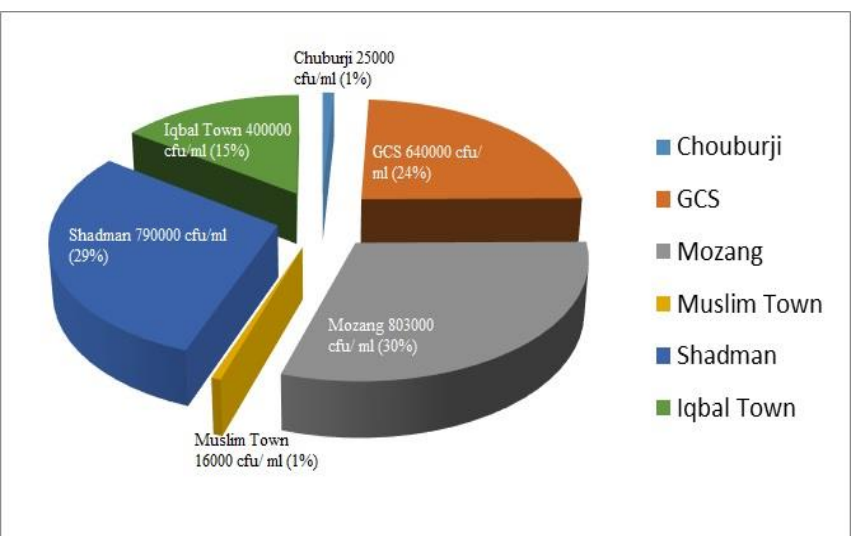

Figure 4. Comparison of total mould count in packed juices of different localities of Lahore.

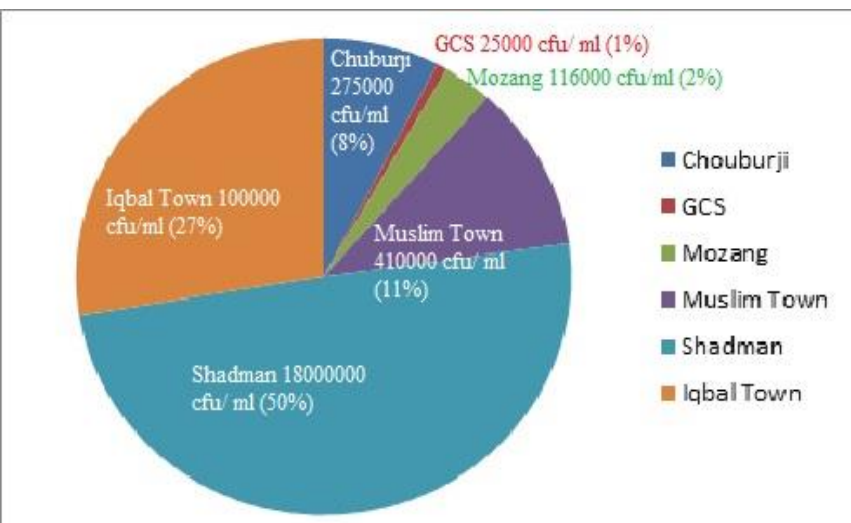

Figure 5. Comparison of mould value in total mould count in unpacked juices of different localities of Lahore.

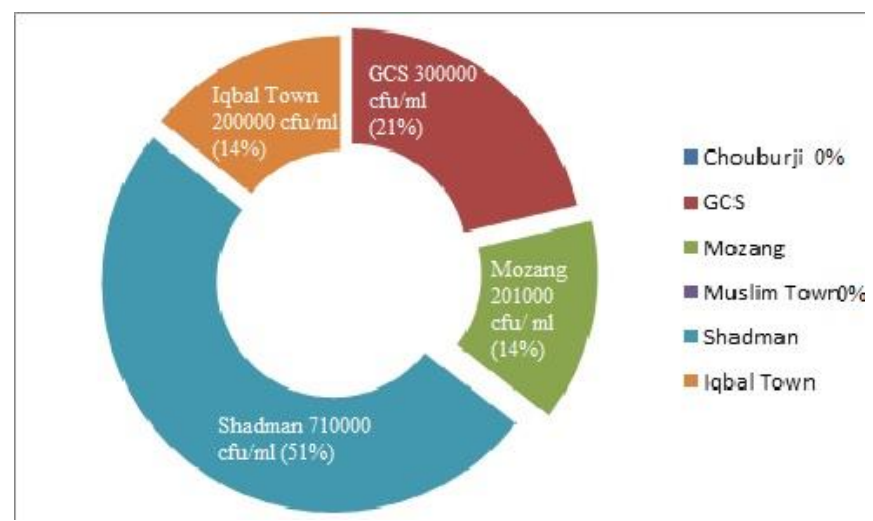

Figure 6. Comparison of total yeast count in packed juices of different localities of Lahore.

Total viable count in unpacked juices: In case of unpacked juices the total viable count was estimated as $16 \times 10^{-3}$ to $27 \times 10^{-4}, 4 \times 10^{-4}$ to $7 \times 10^{-3}, 64 \times 10^{-3}$ to $3 \times 10^{-5}, 11 \times 10^{-4}$ to $5 \times 10^{-}$ ${ }^{5}, 8 \times 10^{-5}$ to $14 \times 10^{-5}$ and $18 \times 10^{-5}$ to $2 \times 10^{-3}$ in Chouburji, GCS, Mozang, Muslim Town, Shadman and Iqbal Town respectively. The peak value fungal viable count was found in Shadman $\left(8 \times 10^{-5} 14 \times 10^{-5} 18 \times 10^{-5}\right)$ while minimum was found in GCS $\left(4 \times 10^{-4}\right.$ to $\left.7 \times 10^{-3}\right)$. In unpacked juices the total mould count was 275000, 25000, 116000, 410000, 1800000 and $1000000 \mathrm{cfu} / \mathrm{ml}$ in Chouburji, GCS, Mozang, Muslim Town, Shadman and Iqbal Town respectively. The uppermost value of mould count (1800000 cfu / ml) in unpacked juices was found in Shadman and least mould (25000 cfu / ml) in unpacked juices was found in GCS locality (Fig. 5). In unpacked juices maximum yeast i.e., $400000 \mathrm{cfu} / \mathrm{ml}$ was found in shadman locality and least one $11000 \mathrm{cfu} / \mathrm{ml}$ was reported in chouburji locality (Figure 5 and 7).

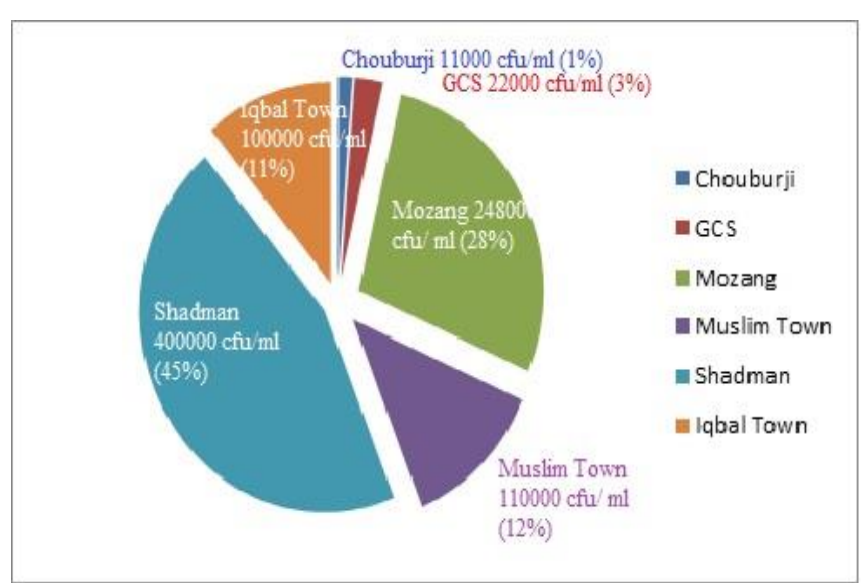

Figure 7. Comparison of total yeast count in unpacked juices of different localities of Lahore.

Mould and yeast diversity in packed juices: The identified fungal and yeast isolates in packed and unpacked juices of all studied localities are reported as Aspergillus niger, A.terreus, Penicilium digitatum, Curvularia americanna, Fusarium moniliforme, Alterneria alternata and Saccharomyces cerevisae. Out of all seven fungal isolates Penicilium digitatum, Aspergillus niger and Saccharomyces cerevisae were present at their maximum peak in all localities. Maximum percentage of Aspergillus niger (42.85\%) was found in locality of Muslim Town, A. terreus (33.33\%) in locality of Iqbal Town, Alterneria alternate (14.28\%) in locality of Chouburji, Penicilium digitatum (42.85\%) in Chouburji, Curvularia americanna (15.38\%) in GCS, Fusarium moniliforme (16.67\%) in Iqbal Town and Saccharomyces cerevisae (33.33\%) in localaties of Shadman and Iqbal Town (Figure 8).

Mould and yeast diversity in unpacked juices: Mould and yeast in unpacked juices illustrated that maximum value of Aspergillus niger (51.16\%) was found in Chouburji, A. terreus $45.45 \%$ in GCS, Alterneria alternata $(25.58 \%)$ in Chouburji, Penicillium digitatum (22.72\%) in Shadman, Curvularia americanna 9.09\% in Shadman, Fusarium moniliforme and Sacharomyces cerevisae both are found to be 50\% in Shadman and Iqbal Town, respectively (Figure 9). 


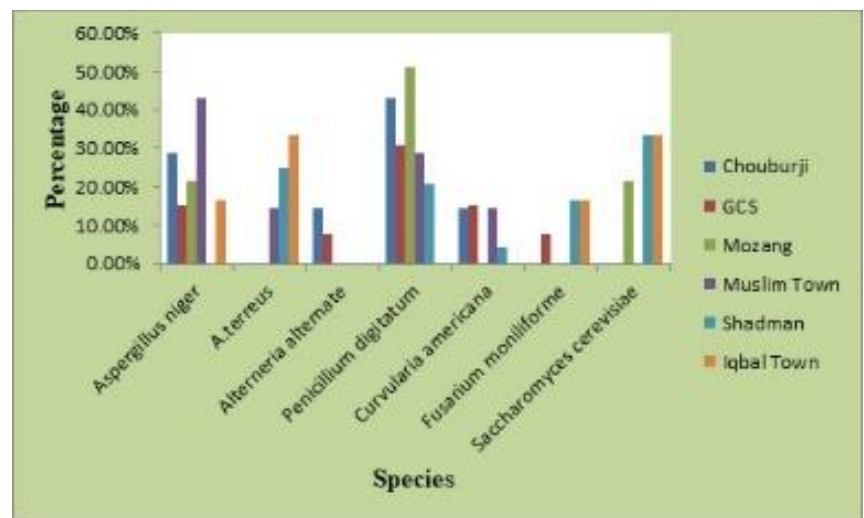

Figure 8. Comparison of percentage fungal isolates in packed juices of different localities of Lahore.

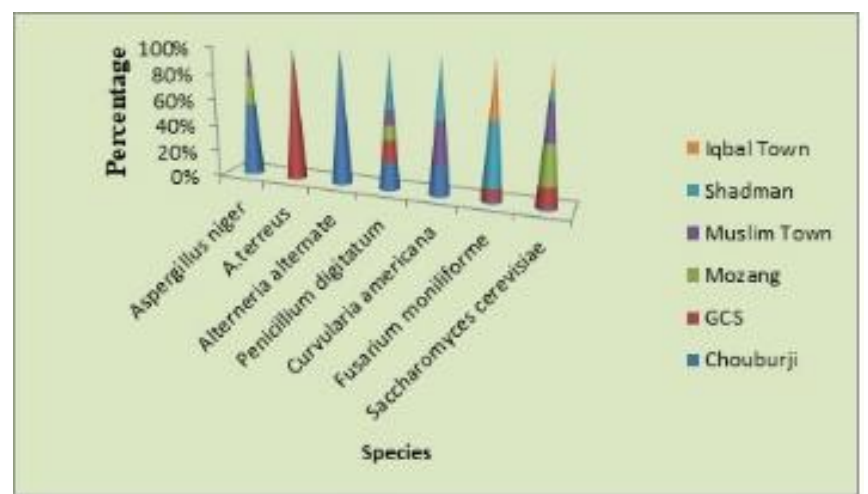

Figure 9. Comparison of percentage fungal isolates in unpacked juices of different localities of Lahore.

Conclusion: According to FDA (2013), the acceptable value of mould and yeast in beverages and juices is $10^{2}$ to $10^{3} \mathrm{cfu} / \mathrm{ml}$ and the level when exceed would cause the rejection of the sample as it indicates potential health hazards and imminent spoilage respectively. The present study indicates much more value of mould $(803000 \mathrm{cfu} / \mathrm{ml}$ to $1800000 \mathrm{cfu} / \mathrm{ml})$ and yeast (200000 cfu/ml to $400000 \mathrm{cfu} / \mathrm{ml}$ ) as compared to standard values in all the tested samples. None of the sample was found safe for consumption. The most frequently occuring fungal species are reported as Aspergillus niger and Sacharomyces cerevisae in packed juices while Penicillium digitatum and Aspergillus niger predominantly found in unpacked juices. This was due to poor handling, and temperature difference in localities. This is quite alarming situation for local community as the health of community is at risk. The microbiological quality of processed fruit juices is the most important aspect to be taken care of by the manufacturers and also the consistency of temperature while preservation and subsequent storage. Negligence in this area may result in serious contamination that ultimately represents a low quality product to the consumers, as these unwanted unhygienic conditions are usually due to the lack of knowledge and unawareness.
Hence a considerable attention is required for sustainability of healthy community.

\section{REFERENCES}

Al-Hindi, R.R., A.R. Al-Najada and S.A. Mohamed. 2011. Isolation and identification of some fruit spoilage fungi: Screening of plant cell wall degrading enzymes. Afr. J. Micro. Res. 5:443-448.

Barth, M., T.R. Hankinson, H. Zhuang and F. Breidt. 2009. Microbiological spoilage of fruits and vegetables. In: W.H. Sperber and M.P. Doyle (eds.), Compendium of the Microbiological Spoilage of Foods and Beverages, Food Microbiology and Food Safety: C Springer Science+ Business Media, LLC; pp.135-183.

Basar, M.A. and S.R. Rehman. 2007. Assessment of microbiological quality of processed fruit juice. Bangl. J. Micro. 24:166-168.

Beuchat, L.R. and D.A. Golden. 1989. Antimicrobials occurring naturally in foods. Food Tech. 43:134-142.

Dehoog, G.S., J. Guarru, J. Gene and M.J. Figuerasm. 2000. Atlas of clinical fungi. -Central bureau voor Schimmel cultures, Mycopathologia, Utrecht, and The Netherlands; pp.159-160.

Denning, D.W. 1998. Invasive aspergillosis. Clin. Infect. Dis. 26:781-805.

Durgesh, P.M., G.K. Ranjana and K.V. Varsha. 2008. Microbiological analysis of street vended fruit juices from Mumbai city, India. Int. J. Food. Safety 10:31-34.

FDA. 1999. Fruit morphology and composition. Center for Food Safety and Applied Nutrition, United States Food and Drug Administration.

FDA. 2013. Revised guidelines for the assessment of microbiological quality of processed food: Republic of the Philipines, Department of Health Food and Drug Administration. Filinvest corporate city, Alabang Muntinlupa, city.

ICMSF. 1980. Microbial Ecology of Foods. 1. Factors Affecting Life and Death of Microorganisms. International Commission on Microbiological Specification for Foods (ICMSF). Academic Press, Orlando; p.311.

Koc, A.N., F.M. Sariguzel, S. Silici and O. Sagdic. 2007. Antifungal activity of propolis in four different fruit juices. Food Technol. Biotechnol. 45:57-61.

Kumari, V. 1995. Nutritional and microbial quality of sugarcane juice in Udaipur city. M.Sc. Dissertation, RAU, Bikaner.

Levine, M. 1961. Facts and fancies of bacterial indices in standards for water and foods. Food Technol. 15:29-34.

Mau, K.A., R.A. Carter, F. Crippa, A. Wald and L. Correy. 2002. Epidemiology and outcome of mold infections in haematopiotic stem cell transplant recipients. Clin. Infect. Dis. 37:909-917. 
Nazim, S., S. Dawar, M. Tariq and M.J. Zaki. 2008. Quantitative estimation of mycoflora in drinking water and fruit juices of Karachi. Pak. J. Bot. 40:1263-1268.

Nicolas, B., B.A. Razack, I. Yollande, S. Aly, O.C.A. Tidiane, N.A. Philippe, C. DeSouza, T.A. Sababénédjo. 2007. Street-Vended Foods Improvement: Contamination Mechanisms and Application of Food Safety Objective Strategy: Critical Review. Pak. J. Nutri. 6:1-10.

Oliveira, A.C.G., A.S.S. Seixas, C.P. Sousa and C.W.O. Souza. 2006. Microbiological evaluation of sugarcane juice sold at street stands and juice handling conditions in São Carlos, São Paulo, Brazil. Cad. Saúde Pública, Rio de Janeiro 22:1111-1114.

Olorunjuwan, O.B., K.B. Temitope, O. Afolabi and O.F. Muibat. 2013. Microbiological quality of some locally produced fruit juices in Ogun state, south western Nigeria E3. J. Micro. Res. 2:1-8.

Oranusi, U.S., W. Braide and H.O. Nezianya. 2012. Microbiological and chemical quality assessment of some commercially packed fruit juices sold in Nigeria. Greener. J. Biol. Sci. 2:1-6.

Palou, E., A. Lopez-Malo, G. Barbosa, J. Welti, P. Davidson and S. Swanson. 1998. Effect of oscillatory high hydrostatic pressure treatments on Byssochlamys nivea ascospores suspended in fruit juice concentrates. Lett. Appl. Micro. 27:375-378.

Parish, M.E. 1991. Microbial Concern in Citrus Juice Processing. J. Food Technol. 45:128-132.
Parish, M.E. and D.P. Higgins. 1989. Yeasts and molds isolated from spoiling citrus products. J. Food. Prot. 52:261-263.

Pitt, J. and A.D. Hocking. 2009. Fungi and Food Spoilage. Springer, New York, NY, USA, $3^{\text {rd }}$ Ed.

Rahman, T., S. Hasan and R. Noor. 2010. An assessment of microbiological quality of some commercially packed and fresh fruit juice in Dhaka city: A comparative study. Stamford. J. Micro. 1:13-18.

Sharma, P.U. 2013. Bacteriological analysis of street vended fruit juices available in vidarbha. Int. J. Curr. Micro. Appl. Sci. 2:178-183.

U.S. Department of Agriculture, Agricultural Research Service. 2004. USDA Food and Nutrient Database for Dietary Studies (release 1.0) [database]. Food Surveys Research Groupwebsite: http://www.barc.usda.gov/ bhnrc/foodsurvey/home.htm.

Victorian Government Department of Human Services, Food Safety Unit Melbourne, Victoria. 2005. Microbiological survey of freshly squeezed juices from retail businesses across Victoria.

Wang, J., L.M. Frostman and M.D. Ward. 1992. Selfassembled thiol monolayers with carboxylic acid functionality: measuring $\mathrm{pH}$-dependent phase transitions with the quartz crystal microbalance. J. Phys. Chem. 96:5224-5228.

Webster, J. and R.W.S. Weber. 2007. Introduction to Fungi, $3^{\text {rd }}$ Ed. Cambridge: Cambridge University Press; pp.434439. 